\title{
EFEKTIVITAS REBUSAN DAUN MUNTINGIA CALABURA L SEGAR DAN KERING SEBAGAI PENURUN HIPERGLIKEMIA PADA MENCIT
}

\author{
Hasma $^{\bowtie}$, Suryanita \\ Jurusan D3 Farmasi STIKES Nani Hasanuddin Makassar
}

\section{ARTICLE INFO \\ Article history \\ Submitted : 2020-10-15 \\ Revised : 2020-11-07 \\ Accepted : 2020-12-23}

\section{Keywords: \\ Cherry Leaves \\ Hyperglycemia \\ Mus Musculus}

\section{Kata Kunci:}

Daun Kersen

Hiperglikemia

Mus Musculus

\begin{abstract}
Muntingia Calabura $L$ is one of the plants that can reduce hyperglycemia which has an antioxidant effect. This effect is due to its high content of flavonoids that can inhibit the oxidation process. This study aims to determine the effectiveness of fresh and dry cherry leaves decoction in reducing hyperglycemia in mice (Mus-Musculus). The study used a laboratory-experimental design with a glucose induction method using 24 male mice divided into eight groups: positive control (metformin), negative control (aquadest), three groups of cherry leaves (fresh and dry) with a concentration of 5\%, $10 \%$, and $15 \%$. Each group consisted of 3 male mice. The results showed that an effective decrease was in the positive control of metformin $113 \mathrm{mg} / \mathrm{dl}$, following a $15 \%$ concentration in fresh leaves $88 \mathrm{mg} / \mathrm{dl}$, and $15 \%$ dry leaves $79 \mathrm{mg} / \mathrm{dl}$. The conclusion in this study was that there was no significant difference between the stew of fresh cherry leaves and dried cherry leaves. The decoction of fresh cherry leaves and dried cherry leaves were both effective in reducing mouse hyperglycemia at a concentration of $15 \%$. It is suggested for further research to use fresh and dry cherry leaf extract samples using other methods.
\end{abstract}

\begin{abstract}
Daun kersen merupakan salah satu tanaman yang berkhasiat sebagai penurun hiperglikemia yang memiliki efek antioksidan, efek tersebut disebabkan oleh kandungannya yang tinggi akan flavonoid yang mampu menghambat proses oksidasi. Penelitian bertujuan mengetahui efektivitas rebusan daun kersen segar dan kering terhadap penurunan hiperglikemia pada hewan uji mencit (Mus-Musculus). Penelitian menggunakan desain eksperimental laboratorium dengan metode induksi glukosa. Menggunakan 24 ekor mencit jantan dibagi menjadi 8 kelompok, kontrol positif (metformin), kontrol negatif (aquadest), 3 kelompok daun kersen (segar dan kering) konsentrasi 5\%, 10\% dan 15\%. Tiap kelompok terdiri dari 3 ekor mencit jantan. Hasil penelitian menunjukkan bahwa penurunan yang efektif ada pada kontrol positif metformin $113 \mathrm{mg} / \mathrm{dl}$ dan menyusul konsentrasi $15 \%$ pada daun segar $88 \mathrm{mg} / \mathrm{dl}$ dan daun kering $15 \% 79 \mathrm{mg} / \mathrm{dl}$. Kesimpulan dalam penelitian ini adalah tidak ada perbedaan nyata antara rebusan daun kersen segar dan rebusan daun kersen kering. Rebusan daun kersen segar dan rebusan daun kersen kering sama-sama efektif menurunkan hiperglikemia mencit pada konsentrasi $15 \%$. Disarankan untuk penelitian selanjutnya menggunakan sampel ekstrak daun kersen segar dan kering dengan menggunakan metode lain.
\end{abstract}

Corresponding Author:

Hasma

Jurusan D3 Farmasi STIKES Nani Hasanuddin Makassar

Telp. 0821343852595

Email: hasmaazzah@gmail.com

\section{PENDAHULUAN}

Menurut WHO (World Health Organization), peningkatan jumlah pasien Diabetes Melitus (DM) di Indonesia, tahun 2000 dari 8,4 juta menjadi sekitar 21,3 juta pada tahun 2030, dan dilaporkan akan meningkat $2-3$ kali lipat di tahun 2035 (Soelistijo et al., 2015).

Diabetes Melitus merupakan salah satu penyakit kronik yang berjangka panjang dan berbahaya bagi tubuh penderita. Penyakit ini apabila dibiarkan akan berdampak pada metabolisme proses penyerapan gula oleh tubuh (Hidayat, 2017). Sehingga tubuh sudah tidak dapat menghasilkan atau memproduksi insulin secara baik. Insulin merupakan hormon polipeptida, berada pada saluran cerna glukosa darah yang tinggi, yang diambil oleh pengangkut glukosa masuk ke sel ßeta-pankreas yang berfungsi dalam menghasilkan energi 
(Nurul Afifah, 2016). Penyakit DM juga disebut dengan hiperglikemia. Hiperglikemia dapat merangsang pembentukan radikal bebas oleh sebab itu, diperlukan antioksidan untuk dapat menangkal radikal bebas (Aligita et al., 2018).

Pemanfaatan obat-obatan herbal sekarang ini terus berkembang dengan pesat dimasyarakat. Keadaan ini didukung oleh berbagai faktor serta isu-isu yang berkembang berupa sikap kembali ke alam (back to nature) (Siahaan \& Lindarto, 2017). Oleh karena itu diperlukan pengujian secara ilmiah menyangkut kemampuan tanaman untuk digunakan sebagai obat tradisional terutama tanaman yang mengandung efek antioksidan.

Salah satu tanaman yang berkhasiat sebagai antioksidan yang dapat menurunkan kadar gula darah adalah daun kersen memiliki kandungan metabolit sekunder seperti flavonoid (Jain et al., 2013). Flavonoid yang berkhasiat sebagai antioksidan terdiri dari flavones, flavonones, katekin dan isoflavon. Flavonol terdiri dari kersetin, kamferol dan myricetin. Senyawa flavanoid berupa flavonols yang diduga memiliki kemampuan dalam penurunan kadar gula darah adalah kuersetin. Kuersetin bekerja menjaga sel $\beta$ pankreas secara normal (Norma \& Hadrayanti, 2019). Penelitian juga menyebutkan, flavonoid memiliki mekanisme dalam proses absorpsi glukosa di jaringan perifer, serta memperbaiki kerja enzim yang terlibat pada proses karbohidrat (Brahmachari, 2011).

Daun kersen mengandung jenis senyawa flavonoid yang berkhasiat untuk digunakan sebagai obat antidiabetik, antikanker, anti-inflamasi dan antipiretik (Mahmood et al., 2014). Selain itu, daun kersen, mengandung senyawa kimia chalcone dan tanin. Chalcone berkhasiat menurunkan kadar glukosa darah, dengan jalan meningkatkan sensitasi insulin, menurunkan glukoneogenesis oleh hati, serta meningkatkan kadar hormon Glucagon-like Polypeptide-1 sebagai regulator glukosa pada usus halus. Tanin, dapat menurunkan kadar glukosa darah dengan cara meningkatkan ambilan glukosa melalui aktivasi Phosphoinositide 3-Kinase dan Mitogen-Activated Protein Kinase (Damara \& Sukohar, 2018). Ekstrak daun kersen berpotensi sebagai antioksidan dan anti hiperglikemia dalam model hewan kekurangan insulin (Aligita et al., 2018).
Banyak penelitian-penelitian yang telah dilakukan tentang khasiat senyawa daun kersen (Muntingia Calabura L) sebagai penurun kadar glukosa darah. Namun, perbedaan mendasar pada penelitian ini, yaitu peneliti menggunakan sediaan rebusan daun kersen segar dan kering. Hal tersebut dikarenakan masyarakat umumnya menggunakan daun kersen segar dengan cara direbus secara langsung dan daun kersen yang dikeringkan terlebih dahulu kemudian diseduh. Sehingga hal ini menjadi pertimbangan peneliti untuk menguji efektivitas antara kedua sampel tersebut dengan metode perebusan. Keuntungan metode perebusan karena metode tersebut mudah dilakukan dan menggunakan peralatan yang sederhana. Berdasarkan uraian tersebut, peneliti ingin mengetahui efektivitas rebusan daun kersen segar dan kering sebagai penurun hiperglikemia pada mencit (Mus Musculus).

\section{METODE PENELITIAN Jenis Penelitian}

Jenis penelitian yang digunakan adalah penelitian Experimental dengan menggunakan daun Kersen (Muntingia Calabura L) untuk mengetahui efektivitas rebusan daun kersen segar dan kering terhadap penurun hiperglikemia pada mencit (Mus Musculus) dengan menggunakan glukosa sebagai penginduksi.

Hewan uji yang digunakan adalah Mencit jantan Galur Swiss Webster berjumlah 24 ekor mencit umur $2-3$ bulan. Mencit diperoleh dari Laboratorium Farmasi Stikes Nani Hasanuddin Makassar. Seluruh mencit dikandangkan pada kondisi bebas patogen dan diadaptasikan pada kondisi laboratorium dengan pemberian makanan biasa dan diberi siklus penerangan 12 jam gelap, dan 12 jam terang.

\section{Lokasi dan Waktu Penelitian}

Penelitian berlokasi di laboratorium Farmakologi Jurusan Farmasi Stikes Nani Hasanuddin Makassar. Penelitian dilaksanakan pada bulan Agustus - Oktober 2020.

Penelitian ini telah mendapat surat kelayakan etik (ethical clearance) dari Universitas Muslim Indonesia (UMI) dengan Nomor. 114/A.1/KEPK-UMI/XI/2020.

\section{Populasi dan Sampel}

Populasi penelitian adalah daun kersen yang ada di Kelurahan Macanre, Kecamatan 
Lilirilau, Kabupaten Soppeng. Sampel penelitian ini terdiri dari daun segar dan daun kering konsentrasi 5\%, 10\%, dan 15\% untuk direbus secara langsung dan daun kering yang dikeringkan terlebih dahulu kemudian direbus.

\section{Pengumpulan Data \\ Pengambilan Bahan}

Daun Kersen (Muntingia calabura L) yang diambil di Kelurahan Macanre, Kecamatan Lilirilau, Kabupaten Soppeng. Pengambilan dilakukan dari daun kelima dari pucuk dengan memilih daun yang segar, tidak busuk. Pengambilan sampel dipilih pada waktu pagi hari yaitu pada pukul 09.00 - 11.00 Wita.

\section{Pengolahan Bahan}

Daun Kersen (Muntingia Calabura L) kering yang sudah diambil dicuci dengan air mengalir hingga bersih dari kotoran dilakukan sortasi basah selanjutnya dipotong kecil-kecil, lalu dikeringkan dengan cara di angin anginkan. kemudian ditimbang lalu dibuat rebusan.

\section{Pembuatan Rebusan Daun Kersen}

Daun Kersen (Muntingia Calabura L) segar dan kering masing-masing dibuat rebusan dalam tiga konsentrasi 5\%, 10\%, 15\%. Rebusan dengan menggunakan konsentrasi $5 \%$ dibuat dengan cara yaitu ditimbang sebanyak 5 gram daun kersen segar, dimasukkan ke dalam panci dengan aquadest sebanyak $200 \mathrm{ml}$ kemudian dipanaskan hingga mendidih.

Proses perebusan selesai apabila air rebusan tersisa $100 \mathrm{ml}$ dari volume air awal, didinginkan, dan disaring dengan kertas saring hingga diperoleh rebusan dengan konsentrasi 5\%. Apabila yang diperoleh kurang dari 100 ml, maka ditambahkan air panas secukupnya melalui ampas hingga volumenya mencapai 100 ml. Dilakukan dengan metode yang sama dengan menimbang daun Kersen konsentrasi $10 \%$ dan $15 \%$.

\section{Pembuatan Larutan Glukosa}

Ditimbang sebanyak 15\%b/v glukosa dimasukkan ke dalam Erlenmeyer $100 \mathrm{ml}$, kemudian ditambahkan aquadest $50 \mathrm{ml}$ dan diaduk hingga larut dan dicukupkan volumenya hingga $100 \mathrm{ml}$.

\section{Pembuatan Larutan Metformin}

Dosis metformin yang digunakan adalah dosis sediaan $500 \mathrm{mg}$. Dosis ini kemudian dikonversi ke dalam dosis untuk mencit yaitu dikalikan dengan faktor konversi dari manusia ke mencit 0,0026. Maka dosis metformin untuk mencit adalah $500 \mathrm{mg}$ x $0,0026=1,3 \mathrm{mg} / 20 \mathrm{~g} \mathrm{BB}$. Selanjutnya metformin ditimbang yang diperoleh dengan cara:

Bobot yang Ditimbang $=\frac{\text { Bobot yang Dïnginkan }}{\text { Dosis Etiket }} x$ Bobot Rata-Rata

Hasil metformin yang didapatkan kemudian dilarutkan dengan aquadest dan dicukupkan volumenya hingga $10 \mathrm{ml}$.

\section{Pemeliharaan dan Penyiapan Sampel}

Hewan uji yang digunakan dalam penelitian adalah mencit (Mus Musculus) jantan dewasa dengan berat badan $20-30 \mathrm{~g}$, digunakan 24 ekor mencit terdiri dari 8 kelompok kontrol positif (metformin), kelompok kontrol negatif (Aquadest).

$$
\text { Kelompok daun kersen segar }
$$

(konsentrasi 5\%, 10\%, dan 15\%) dan kelompok daun kersen kering (Konsentrasi 5\%, $10 \%$, dan 15\%). Tiap kelompok terdiri dari 3 ekor mencit dan sebelum perlakuan diaklimasikan selama 7 hari dan pada hari ke- 8 dipuasakan selama 8 jam.

\section{Perlakuan terhadap Hewan Uji}

Hewan uji ditimbang berat badannya untuk diketahui apakah hewan tersebut sehat dan baik digunakan. Setelah dilakukan pemeriksaan pada hewan uji, kemudian diberikan tanda, dipuasakan selama 8 jam (tetap diberi air minum sebagai pengganti cairan tubuh yang hilang selama dipuasakan). Setelah 8 jam dipuasakan, di periksa kadar glukosa darah awal mencit. kemudian semua hewan uji diinduksi glukosa secara oral agar mencit mengalami hiperglikemia dengan volume 0,2 $\mathrm{ml} / 20 \mathrm{~g} \mathrm{BB}$ mencit (Stevani et al., 2017).

Setelah mencit dinyatakan sudah hiperglikemia, maka tiap kelompok mencit mendapat perlakuan, kelompok 1 kontrol positif sebagai sebagai pembanding diberikan suspensi metformin, kelompok 2 kontrol negatif (aquadest), kelompok 3, 4, dan 5 diberikan masing-masing rebusan daun Kersen dengan konsentrasi 5\%, 10\%, dan 15\%. Pengamatan dinilai setelah pemberian perlakuan seperti diatas, dengan cara menggunting ekor mencit lalu diambil darahnya menggunakan strip dan dibaca kadar glukosa darah pada glukometer. 
Dilakukan pada menit ke 30, 60, 90 dan 120, kemudian diamati dan dicatat.

\section{Pengolahan dan Analisis Data}

Data yang diperoleh dari hasil pengukuran dikumpulkan dalam tabel dan diolah menggunakan komputer program SPSS.

\section{HASIL PENELITIAN}

Berdasarkan tabel 1, hasil rata-rata pengukuran KGDP mencit 87 - 100,33 mg/dl. Hasil pengukuran ini sesuai dengan kadar glukosa darah normal darah berkisar antara 70 $117 \mathrm{mg} / \mathrm{dl}$ (Dewiyeti \& Hidayat, 2015). Mencit yang telah diinduksi dengan glukosa menunjukkan adanya peningkatan kadar gula darah berkisar 157,67 - 184,66 mg/dl.

Mencit tersebut dapat dikatakan sudah mengalami kondisi hiperglikemia dilihat dari rata-rata kadar glukosa darah yang melebihi normal. Mencit yang telah diberi perlakuan mengalami penurunan hiperglikemik dimulai pada menit 30 - 120. Dimana Penurunan yang efektif ada pada kontrol positif metformin 113 $\mathrm{mg} / \mathrm{dl}$ dan menyusul konsentrasi $15 \%$ pada daun segar $88 \mathrm{mg} / \mathrm{dl}$ dan daun kering $15 \% 79$ $\mathrm{mg} / \mathrm{dl}$.

Tabel 1. Hasil Rata-Rata Penurunan Hiperglikemia pada Masing-Masing Perlakuan

\begin{tabular}{|c|c|c|c|c|c|c|c|}
\hline \multirow{2}{*}{ Kelompok Perlakuan } & \multirow{2}{*}{ KGDP } & \multirow{2}{*}{ KGDI } & \multicolumn{4}{|c|}{$\begin{array}{c}\text { Penurunan } \\
\text { Hiperglikemia (Menit) } \\
\end{array}$} & \multirow{2}{*}{$\begin{array}{c}\text { Rata-Rata } \\
\text { Penurunan } \\
\text { Hiperglikemia } \\
\text { (mg/dl) }\end{array}$} \\
\hline & & & $\mathbf{T} / \mathbf{3 0}$ & T/60 & T/90 & $\mathbf{T} / \mathbf{1 2 0}$ & \\
\hline Kontrol (+) Metformin & 87 & 184,66 & 138,66 & 115 & 94,67 & 71,33 & 113,33 \\
\hline Kontrol (-) Aquadest & 99,33 & 166,33 & 160,33 & 132,66 & 121,33 & 105,66 & 60,67 \\
\hline DS 5\% & 89 & 161,33 & 149 & 134 & 116,33 & 90,33 & 71,00 \\
\hline DS $10 \%$ & 95,33 & 164,33 & 147 & 120,33 & 106,33 & 87.33 & 77,00 \\
\hline DS $15 \%$ & 74,33 & 172,33 & 139,33 & 114 & 101,66 & 84,33 & 88,00 \\
\hline DK 5\% & 96 & 167 & 156 & 142,67 & 119,63 & 101,67 & 65,33 \\
\hline DK $10 \%$ & 100,33 & 157,67 & 151,33 & 135,33 & 110,67 & 82 & 75,67 \\
\hline DK $15 \%$ & 89,67 & 171,33 & 144,33 & 115 & 111,33 & 92,33 & 79,00 \\
\hline
\end{tabular}

Keterangan:

KGDP : Kadar Gula Darah Puasa

KGDI : Kadar Gula Darah Induksi

DS : Daun Segar

DK : Daun Kering

Pada gambar 1 menunjukkan grafik 120. Semua kelompok mengalami penurunan penurunan hiperglikemik pada masing-masing hiperglikemik. Penurunan yang efektif ada pada kelompok perlakuan pada rebusan daun kersen kontrol positif metformin dan konsentrasi $15 \%$. segar. Terlihat pada menit ke 30, 60, 90 dan

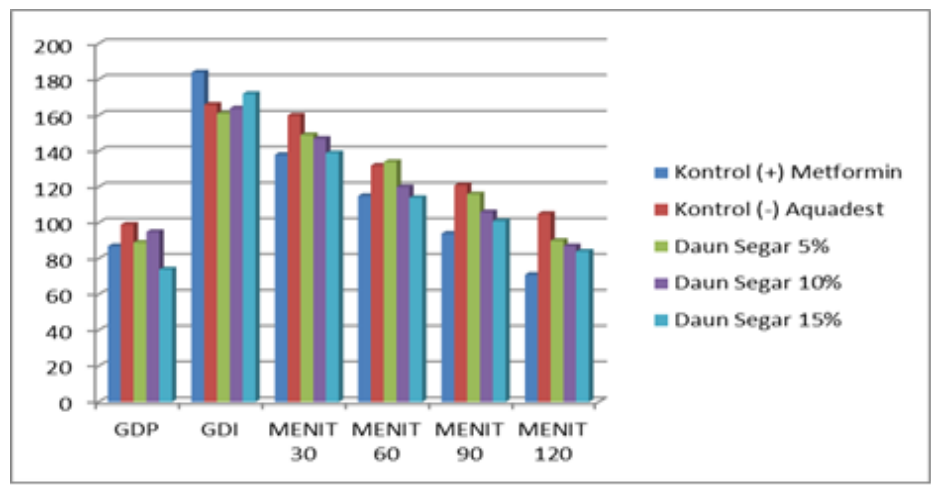

Gambar 1. Grafik Penurunan Hiperglikemia Mencit (Mus Musculus) pada Daun Kersen Segar 
Pada gambar 2 menunjukkan grafik penurunan hiperglikemik pada masing-masing kelompok perlakuan pada rebusan daun kersen kering mulai dari menit ke 30, 60, 90 dan 120. Semua konsentrasi pada daun kersen kering mengalami penurunan hiperglikemik. Penurunan yang efektif pada kontrol positif metformin dan konsentrasi $15 \%$.

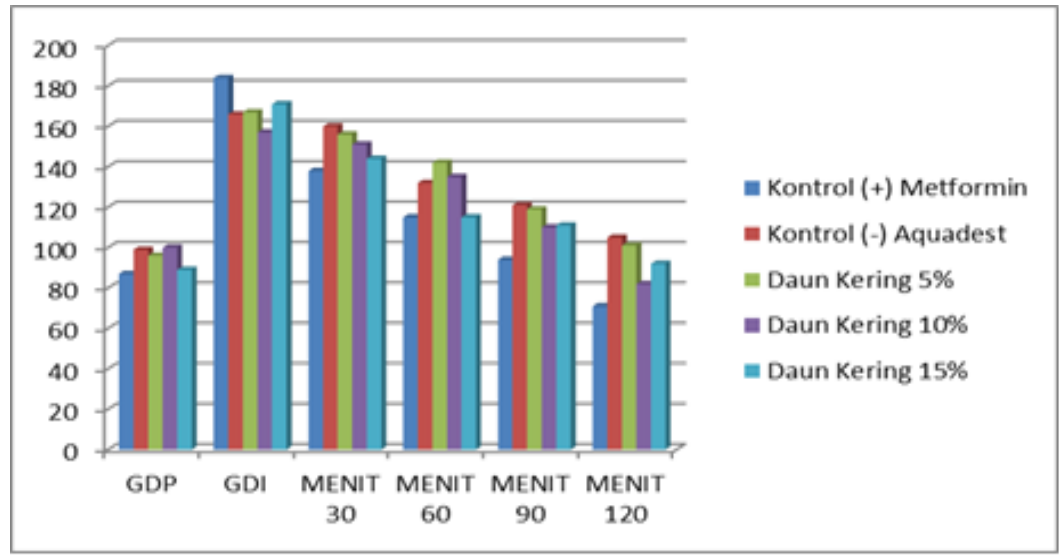

\section{Gambar 2. Grafik Penurunan Hiperglikemia Mencit (Mus Musculus) pada Daun Kersen Kering}

\section{PEMBAHASAN}

Pada tahap awal penelitian ini dilakukan uji penurunan kadar glukosa darah menggunakan uji induksi glukosa secara oral yang dilakukan dengan mengondisikan keadaan diabetes pada hewan uji dengan cara menginduksi hewan uji dengan zat kimia yang mampu menaikkan kadar hiperglikemia pada hewan coba. Dimana prinsip kerja dari glukosa adalah membebani hewan coba dengan glukosa hingga mengalami hiperglikemik tanpa harus merusak pankreas (Tukayo et al., 2018).

Hewan yang digunakan pada penelitian ini yaitu mencit jantan dewasa. Penggunaan mencit jantan (Mus Musculus) karena memiliki sistem siklus reproduksi yang lebih stabil, singkat, memiliki generasi yang pendek serta dapat menghasilkan keturunan yang banyak. Sebelum melakukan penelitian, mencit diadaptasikan terlebih dahulu, dan selanjutnya dipuasakan selama 8 jam dengan maksud untuk mempercepat reabsorbsi obat sebab pengosongan lambung akan mempercepat proses penyerapan obat dan dikhawatirkan apabila tidak dipuasakan, makanan serta minuman dapat memicu hasil penelitian.

Pemberian larutan glukosa pada mencit dilakukan 1 jam sebelum perlakuan bertujuan menaikkan kadar gula darah mencit. Glukosa yang digunakan sebagai penginduksi pada mencit yaitu glukosa $15 \%$ b/v, volume pemberian ke mencit $0,2 \mathrm{ml} / 20 \mathrm{~g} \quad \mathrm{BB}$.
Pemberian induksi glukosa secara oral pada mencit telah berhasil menaikkan kadar glukosa pada masing-masing hewan uji. Hal ini berdasar pada literatur bahwa tubuh menyerap glukosa sekitar 30 - 60 menit dan akan mengalami penurunan setelah $2-3$ jam (Stevani et al., 2017).

Penelitian ini menggunakan obat metformin sebagai kontrol positif karena penggunaan metformin tercatat dapat membantu menurunkan kadar gula darah dalam tubuh dengan mengurangi jumlah gula yang diproduksi oleh hati, serta secara bersamaan meningkatkan kemampuan penyerapan gula dari otot-otot. Metformin juga jarang dilaporkan menyebabkan hipoglikemia (Gumantara \& Oktarlina, 2017). Pada penelitian ini menggunakan aquadest sebagai kontrol negatif, karena metformin menurut farmakope edisi IV kelarutannya, mudah larut dalam air.

Pada pengukuran kadar glukosa darah menggunakan alat Glukometer $G l u c o D r^{\mathrm{R}}$ untuk mengukur kadar glukosanya. Prinsip alat tersebut adalah bekerja secara enzimatis berdasarkan reaksi glukosa oksidase, Glukosa dalam darah akan bereaksi dengan glukosa oksidase serta kalium ferisianida yang ada pada strip serta menghasilkan kalium ferosianida. Kalium ferosianida yang didapatkan sebanding dengan konsentrasi glukosa yang ada dalam darah. Oksidasi kalium ferosianida akan menghasilkan muatan listrik yang akan diubah 
oleh glukometer untuk ditampilkan konsentrasi glukosa pada layar (Stevani et al., 2017).

Berdasarkan hasil penelitian yang telah diperoleh dari kedelapan kelompok perlakuan, Memperlihatkan nilai rata-rata kadar glukosa darah mencit 87-100 mg/dl. Hasil pengukuran ini sesuai dengan kadar glukosa darah normal darah berkisar antara $70-117 \mathrm{mg} / \mathrm{dl}$. Mencit yang telah diinduksi dengan glukosa menunjukkan adanya peningkatan kadar gula darah berkisar 157,67 - 184,66 mg/dl. Mencit tersebut dapat dikatakan sudah mengalami kondisi hiperglikemia dilihat dari rata-rata kadar glukosa darah yang melebihi normal. Diabetes Melitus atau biasa disebut kencing manis merupakan sindrom hiperglikemia dimana kadar glukosa darah tidak boleh melebihi batas >180 mg/dl (Dewiyeti \& Hidayat, 2015).

Pada masing-masing perlakuan, mencit yang telah diinduksi dengan glukosa menunjukkan penurunan kadar gula darah. Penurunan kadar gula darah maksimal ada pada menit 120. Setiap perlakuan menunjukkan hasil yang berbeda-beda dimulai dari menit 30, 60, 90, dan 120. Dimana Penurunan yang terbesar ada pada kontrol positif metformin 113 /dl, menyusul konsentrasi $15 \%$ pada daun segar 88 $\mathrm{mg} / \mathrm{dl}$ dan daun kering $15 \% 79 \mathrm{mg} / \mathrm{dl}$, dan seterusnya konsentrasi 5\%, 10\% pada daun segar dan daun kering adalah $77 \mathrm{mg} / \mathrm{dl}, 75$ $\mathrm{mg} / \mathrm{dl}, 71 \mathrm{mg} / \mathrm{dl}, 65 \mathrm{mg} / \mathrm{dl}$. Penurunan yang sedikit ada pada kontrol negatif (aquadest) $60,67 \mathrm{mg} / \mathrm{dl}$.

Penurunan kadar gula darah diduga karena adanya senyawa flavonoid yang terdapat pada daun kersen yang memiliki efek antioksidan yang dapat memperbaiki sel-sel $\beta$ pankreas yang rusak. Flavonoid juga diduga dapat memperbaiki daya kerja reseptor insulin, sehingga memperoleh efek yang menguntungkan pada keadaan Diabetes Melitus. Selain itu, antioksidan juga mengikat radikal bebas sehingga dapat mengurangi resistensi insulin (Eryuda \& Soleha, 2016).

\section{KESIMPULAN DAN SARAN}

Berdasarkan hasil penelitian menunjukkan tidak ada perbedaan nyata antara rebusan daun kersen segar dan rebusan daun kersen kering. Rebusan daun kersen segar dan rebusan daun kersen kering sama-sama efektif menurunkan glukosa darah mencit pada konsentrasi 15\%. Disarankan untuk penelitian selanjutnya menggunakan sampel ekstrak daun kersen segar dan kering dengan menggunakan metode lain.

\section{DAFTAR PUSTAKA}

ligita, W., Susilawati, E., Sukmawati, I. K., Holidayanti, L., \& Riswanti, J. (2018). Antidiabetic activities of Muntingia calabura L. leaves water extract in type 2 diabetes mellitus animal models. Indonesian Biomedical Journal, 10(2), 165-170. https://doi.org/10.18585/inabj. v10i2.405.

Brahmachari, G. (2011). Bio-flavonoids with promising anti- diabetic potentials: A critical survey. Opportunity, Challenge and Scope of Natural Products in Medicinal Chemistry-Research Signpost, 661(2), 187-212.

Damara, A., \& Sukohar, A. (2018). Efektivitas Infusa Daun Kersen (Muntingia calabura Linn) Sebagai Antidiabetik Effectivity of Jamaican Cherry Leaf (Muntingia calabura Linn) Infusain as Antidiabetics. J Agromedicine, 5(46), 534-539.

Dewiyeti, S., \& Hidayat, S. (2015). Ekstrak Daun Kelor (Moringa Oleifera Lamk.) sebagai Penurun Kadar Glukosa Darah Mencit Jantan (Mus Musculus L.) Hiperglikemik. Jurnal Penelitian Sains, 17(2), 168388. https://doi.org/DOI: https://doi.org/10.26554/jps.v17i2.52.

Eryuda, F., \& Soleha, T. U. (2016). Ekstrak Daun Kluwih (Artocarpus camansi) Dalam Menurunkan Kadar Glukosa Darah Pada Penderita Diabetes Melitus Kluwih Leaf Extract (Artocarpus camansi) In Lowering Blood Glucose Levels In Patients With Diabetes Melitus. Jurnal Majority, 5(4), 71-75.

Gumantara, M. P. B., \& Oktarlina, R. Z. (2017). Perbandingan Monoterapi dan Kombinasi Terapi SulfonilureaMetformin terhadap Pasien Diabetes Melitus Tipe 2 Comparison of Monotherapy and SulfonylureaMetformin Combination Therapy to Patient with Type 2 Diabetes Mellitus. Jurnal Majority, 6(1), 55-59.

Hidayat, R. (2017). Pengaruh Senam terhadap Kadar Gula Darah pada Penderita Diabetes Melitus Tipe 2 Di RSUD Puri Husada Tembilahan. Jurnal Keperawatan, 1(1), 51-80.

Jain, P., Hossain, K. R., Mishu, T. R., \& Reza, 
H. M. (2013). Antioxidant and Antibacterial Activities of Spondias pinnata Kurz. Leaves. European Journal of Medicinal Plants, 4(2), 183-195. https://doi.org/https://doi.org/10.9734/EJ MP/2014/7048.

Mahmood, N. D., Nasir, N. L. M., Rofiee, M. S., Tohid, S. F. M., Ching, S. M., Teh, L. K., Salleh, M. Z., \& Zakaria, Z. A. (2014). Muntingia calabura: A review of its traditional uses, chemical properties, and pharmacological observations. Pharmaceutical Biology, 52(12), 15981623. https://doi.org/10.3109/ 13880209. 2014.908397.

Norma, \& Hadrayanti, N. (2019). Pengaruh Rebusan Daun Kersen Terhadap Penurunan Gula Darah sewaktu Pada Klien Diabetes Melitus Tipe II Di Wilayah Kerja Puskesmas Klasaman Kota Sorong Tahun 2018. Preventif Journal, 3(2), 6-10. https://doi.org/DOI: http://dx.doi.org/10.37887/epj.v3i2.6068.

Nurul Afifah, H. (2016). Mengenal Jenis-Jenis Insulin Terbaru untuk Pengobatan Diabetes. Farmasetika.Com (Online), 1(4), 1-4. https://doi.org/10.24198/ farmasetika.v1i4.10367.
Siahaan, B. S., \& Lindarto, D. (2017). Pengaruh Puguntano terhadap HOMA-IR Pada Pasien Diabetes Melitus yang Baru Didiagnosis. Majalah Kedokteran Bandung, 49(2), 67-72. https://doi.org/ 10.15395/mkb.v49n2.1051.

Soelistijo, S., Novida, H., Rudijanto, A., Soewondo, P., Suastika, K., Manaf, A., Sanusi, H., Lindarto, D., Shahab, A., Pramono, B., Langi, Y., Purnamasari, D., \& Soetedjo, N. (2015). Konsesus Pengelolaan Dan Pencegahan Diabetes Melitus Tipe2 Di Indonesia 2015. In Perkeni.

Stevani, H., Base, N. H., \& Thamrin, H. A. (2017). Efektifitas Rebusan Daun Kersen (Muntingia calabura L) Terhadap Penurunan Kadar Glukosa Darah Pada Mencit (Mus musculus). Jurnal Kesehatan Yamasi, 1(1).

Tukayo, B. L. A., Titihalawa, D. R., Farmasi, J., Kemenkes, P., Farmasi, J., \& Kemenkes, P. (2018). Rebusan Daun Kersen (Muntingia calabura L.) Menurunkan Glukosa Darah pada Kelinci (Oryctolagus cuniculus). Gema Kesehatan - Poltekes Jayapura, 10(1), 915. https://doi.org/10.47539/gk.v10i1.2. 